\title{
The Political Role of Russia: A Case Study of Central Asian Muslim States
}

\author{
Muhammad Ibrahim (Ph.D Scholar) \\ Lecturer Govt. Postgraduate College Bahawal Nagar \\ Email: prof.ibrahim69@yahoo.com
}

Accepted: March 27, 2015

Doi:10.5296/ jpag.v5i1.7389 URL: http://dx.doi.org/10.5296/ jpag.v5i1.7389

\begin{abstract}
Capitalism and Socialism prevail over and converted world into bipolar. U.S.S.R was super power of world and leader of Eastern Europe and Socialist Block. There was a state of constant confrontation between two Super powers, the United States and the Soviet Union that led to disintegration of USSR. Central Asian states get independence from USSR. It changed the political significance of Russia at global forums. The politics of world converted to unipolar world. Socio-economic reconstruction calls for the strength of a democratic state capable of inspiring its citizen to self-interested voluntary cooperation. Achieving the constructive project, and organizing a social consensus for its implementation. The purpose of study is to analyze vision of political leadership of Russia for dominance in central Asian Muslim states. This perception has started from the day of independence of states of Central Asia. New shift has occurred in the region. The political significance is independent variable and dependency of Asian States is dependent variable with assumption. It is in debate that communism is sufficient political system for survival for regional countries in leadership of Russia.
\end{abstract}

Keywords: Political role, Russian democracy, Muslim states 


\section{Introduction}

In 1985 Gorbachev selected President of USSR. The political and economic situation of USSR is becoming worsened. The slogans of Communism are not simply delivering as the promised workers paradise wages. The lifestyle difference is clearly seen from the 1970s.(Cosgrove)Gorbachev familiarized Glasnost and Perestroika policies to counter this stagnation. Gorbachev espoused the policies of openness and re-structuring in which it will be hopped people to rebuild the communist system in new shape to work better. It is allowed people to criticize openly about political system. The economy of Soviet Union is becoming slowly stagnant. (Gill, 1995, pp. 1140-1141)

The people of Soviet Republics are tired by Russians policies and now they want to be governing themselves. They are started criticize of Glasnost and began to organize protest. Eventually they started protest in the Baltic Republics which are demanding now independence. At last the collapse of the Soviet Union occurred. The conservative communist made try to put in a more Stalinist system in August 1991 but failed and the events pushed Soviet Union into the history books. Russian leadership is desired to reinforce its influence in Central Asian states. It is intensifying in a selective way of trade and Customs Union. This pictured plan would be involved Kyrgyzstan and Tajikistan beyond Kazakhstan and Belarus. It will tough to judge about this situation for long tenure holds and how feasible such strategies will prove. The changes will predictably and ultimately come to the regional countries.(Khan)

\section{Geographical significance of Russian}

U.S.S.R comprised on four major blocks: Baltic States (Balts), the Slavic states (Slavs), Central Asia and the Caucasus. Ukraine, Belarus and Moldova are major countries of the Slavic states. These states have religious and traditional cultural relation with each other from a long period. Latvians, Lithuanians and Estonians are Baltic States which existed on east coast of the Baltic Sea. Central Asian region consists of these states as follow, Uzbekistan, Turkmenistan, Tajikistan, Kyrgyzstan and Kazakhstan. The Caucasus or Caucasia is a region in Eurasia which shared border with Turkey and Iran on South. There is a black Sea on West. Caspian Sea is situated on East side. In North Russian European part is existed. Asia and Europe are divided Caucasus Mountains line. Georgia, Armenia, and Azerbaijan include South Caucasus comprise the nation-states. (Gleason, 1991-1992 pp141-163)

It is inevitable reality that Soviet Union is collapsed historically. The collapse of Soviet Union brought ineffectiveness in provision of the living standards. The majority of the people lower quality of life in these States, including Russia. These issues are consequential numerous conflicts and confrontations in central Asian States.(Lévesque, 1997)Foremost objective of these newly independent states is to define strategic aims with Russia. Economic and political co-operation becomes basic need to support for betterment of region. The military cooperation is need of hour for regional central Asian states. Regional stability is major task after disintegration of Soviet Union. The stability of these central Asian States is the major interest of Russia in the FSU for protection of millions of ethnic Russians. These ethnic Russians are living in these central Asian States. (Wlodek, 2004 pp71-84) 
It was also has to keep in mind to maintain considerable influence in these states with soft attitude policy towards them. Russia is strongly opposite to alliance of North Atlantic Treaty Organization (NATO) as well as European Union (EU). Russian establishment is keeping eye on membership issue of Muslim central Asian states to NATO as Euro-Atlantic community. This issue is considered as a serious challenge as well as intimidating step to Russia. These states have prominence to maintain cordial and friendly relations with Russia. The central Asian states have dependency in many different ways on Russia. Due to these reasons it becomes need to form a policy about checks and balances towards Russia and FSU States. After establishment of central Asian Republics, there are several challenges to Russia. These states have ethnic aspirations, socioeconomic priorities and unique territorial. The newly founded regional states are facing dilemma of West seem to be infatuated. These regional states of central Asia for future repercussions do not want to unstructured relation with Russia.(CDDRL, 1993).It is an endeavor to extricate about issues and challenges in relationship among Russia and FSU states. This article is an attempt to observe linkage among Russia and central Asian states in basis of economic and political dimension. It also focuses on strategic depth among these states and continues to maintain in future with among them. The in paper is fully focused to provide an outline for understanding politico-economic, security and social dimensions central Asian states with Russia. (Kratochwil, 1994)

\section{Russia's Role for Central Asian States}

Today Russia and these regional states of central Asia are core interdependence remains much integral because having joint long borders of $7000 \mathrm{~km}$. There are twelve sections or subekty of Russian Federation which having attached border with central Asian states. There are some areas which are developed industrially as Samara, Volgograd, Chelyabinsk, and Omsk. These areas situated with boarder areas of regional states. The linkage of central Russia is to Siberia and Far East which is strategically important areas in central Asian states. This communications and connection is close to border or somewhat pass through Kazakhstan's area.

The decision maker authority of Russia seeks to counter economically western political and economic interests to gain substantial influence for energy resources of oil and gas. It can be achieved through participation in joint ventures in the region. It is planned to insisting that transit routes of pipeline in the territory of Russia. Russia tried to avoid large monetary subsidizations to regional states at the same time. (Hil, 2005)

The officials of Russia have accentuated interests with these central Asian states. These interests are encircled strategic security and economic ties as well as have concerns over the treatment of ethnic Russians in these states. The main focus of strategic concerns are on drug trafficking and regional conflict to settle down for betterment of regional states. These states make efforts for regional role as a buffer zone with help of Russia from religious extremism. On the other hand, deteriorating situation of economy of Russia is forced to demand Russia reduce its security presence in central Asia. As President Putin came in power in Russia he take starts in search to make political situation reverse. (Linnn, October 2004)

The active role of Russia toward central Asian region in January 2000 is a major shift of 
Russian interests on the issue of national security. It is considered that external intervene made weakened Russia's position in central Asia then Acting President of Russia Putin approved it. Russia stressed to the members of Collective Security Treaty (CST)in April 2000 to accept establishment of rapid reaction forces. The central Asian states are also member of this treaty. The basic objective of this accord is combating issue of terrorism instigating from Afghanistan and having influence of Russia in the region just like USA. (Sdasyuk, 2000 pp42-52)

It is decided in May 2001 that a force composed in light of CST summit which is consisted of a regional states of Asia Kazakhstan, Kyrgyzstan, and Tajikistan. The headquarters of this force is located in Bishkek and battalions of force established force may be present there for some regional challenges. These ingenuities appeared to be part of the aim to protect Russian's influence in this region. This issue has to face due to nascent U.S. and NATO anti-terrorism moves in the region against Afghanistan. The participants of CIS treaty in 2001 permitted to establish a regional Anti-Terrorist Center (composed of intelligence agencies). (Report, September 2004)

\section{9/11 and Significance of Russia in Central Asian States}

The events of 9/11 change global political scenario. After the start of war of terrorism in Afghanistan with support of UN resolution, it may weaken more influence of Russia over the central Asian states. Moreover it is linked with duration and scope of US and coalition forces manifestation in the region. The long-term positioning of US and allied forces are for countervailing policies of Russia. In the Putin era, Russian administration had tried for strengthening of interests in region while opposing the growth of U.S. and other influence prior to 9/11. Now on other reasons Russian is permitting for increase in U.S forces in this region.

Russia perceptibly inverted the policy of drawing down military forces happening in central Asia states. After the incident of 9/11, Russia has increased its military troops in Tajikistan. Russia contracted military settlement in June 2002 with Kyrgyzstan. This agreement make extension of leases for soldierly facilities for the next fifteen years, training Kyrgyz troops and to help in opening closed Kyrgyz defense industries. Kyrgyzstan also agreed for use of Kant airfield as a base for the Central Asian rapid reaction force.

\section{Russian and Central Asian States Economy interdependence}

There is complex western role in energy development in the Caspian. After 9/11environment, Russia's motives give the idea for coherent energy policy for these central Asian states is to follow. Russian foreign affair ministry has softened for policy of mutual energy plane for central Asian states. The edifice of the Baku Tbilisi Ceyhan (BTC) pipeline is implemented utilization of energy resources. Although, the government of Russia is not fully willing for this plane, Russian companies are ready to accept the character for western energy firm in this region. It is observed in January 2002during visit of Turkmen President Niyazov's to Moscow in which Russian President suggested regional states to institute a Eurasian gas alliance. Its function is to export gas through a single network. It is speculated in Russian 
media that the world gas market come under the influence of Eurasian gas alliance. It is advocated to protect the probability of U.S. energy impact in central Asian region.(Libman, 2007 pp 401-430)

Major investment of Russia is notable energy sector in Kazakhstan. The famous Caspian Pipeline Consortium (CPC) is the biggest project of Russian companies in energy sector. The objective of this project is transporting petroleum from Russia and western Kazakhstan to the global market through a terminal of Novorossiysk situated at coast of Black Sea.(Jayashekar, 1993)

The Russian would be hard pressed to meet domestic requirements without Central Asian gas and its obligations to Western and Eastern Europe for gas supply is dependent of these states. Russia will become gradually dependent in future on Central Asian states gas supply. The countries of Central Asia export their gas through the pipeline system of Russia and can maintain their gas extraction and transportation facilities in future with help of Russian.

The purchase of raw materials from each other is the interdependence of Russia and the Central Asia countries which are not available in adequate quantities in their own countries. Uzbekistan production of cotton, natural gas, and tungsten and molybdenum supplies for Russia and receives support of aluminum and the raw materials for the iron and steel industry from Russia.

\section{Russia's Integrationist Approach}

The vested interests in central Asian states are typical apprehension of Russian leadership. It is serving as a political stalking horse for all those in Russia. They are backing the feelings to restore prior Russia's boundaries which include all central Asian states. There are ethnic issues which concerns about Russians residing in Central Asia. They are facing issues of employment, language and other policies. They are deeming discriminatory feelings due to which started migration contributing to their decline from 20 million in 1989 to 6.6 million in 2001.

The foreign policy of Russia has been pursuing an ambitious toward Central Asian republics in recent years. This focus is resulting for creation of organization with participation of Belarus and Kazakhstan. It is hopeful for possible participation of Kyrgyzstan and Tajikistan. It is feel that Kazakhstan to be immersed fully in Russia's integrationist aspirations is the first Central Asia republic. There are different treaties and protocol between Kazakhstan and Russia. There are some of them as membership in Eurasian Economic Community, Customs Union and Common Economic Space, and current stage of strategic partnership. It is also observed in partial loss of sovereignty for Kazakhstan. The establishment of a Eurasian Union may mean the loss of political independence of Astana under the leadership of Russia. The regional aspirations of Russia are not bound for Kazakhstan and Belarus. Kyrgyzstan and Tajikistan is also target of Moscow for actively promotion of accession. This aspiration is not seen clearly in Russian President Vladimir Put in during the first and second term. The situation has changed dramatically today. President Putin, Russia from beginning of the third term is overtly pursuing an ambitious policy towards Central Asia 
that is frequently characterized as neo-imperial.(Mackinder, 1993)

\section{Conclusions}

The paper is actual research component of the summary to argument here about the complex and fluctuating environment of Russia with regional states of central Asian states. It is seemed that Russia is becoming the most protuberant external power in central Asia region after disintegration of USSR. Russia is establishing high-level political relationships, security cooperation and investment projects in the region. China is growing economic power of region and its specific significance as an economic power in Central Asia. Russia is no longer great partnership in trade with five central Asia countries till 2010. For political influence China has to seek growing economic presence in region. Moscow has option to continue in region primarily dominance through the security prism. Russia is more persuaded to deal Central Asian states for own interests. Otherwise there are other risks to be confined either than as opportunity for new inroads or expansion. There is possibility to expose itself the role of regional super power.

The Moscow assessment seems appetite for intervention in Kyrgyzstan; it would almost certainly have been misinterpreted. The non-intervention had no direct political cost in the calculation of Russia. There are different multilateral organizations such as CSTO and SCO that are established for purpose of Russian. The platform of CSTO is used by Russian in sense of implication to strengthen as powerful regional state. The preference of Moscow in the use of CSTO and Eur As EC to escalation influence in regional central Asian states. The CSTO lingering impression is to remain it as mainly ineffective. There will continue to suffer from the lack of a common vision. The Customs Union will be effectively implemented to monitor in the coming years with regard to Kazakhstan, Kyrgyzstan and Tajikistan. It is observed that bilateral relations are based on a differentiated approach. Russia will constitute the main focus for Kazakhstan for interaction and dealings in the region in prime position.

There is lack of regional unity in Moscow's policy towards Central Asia. It is based on designing Russian strategies for country-by-country basis. The basic component of the Russian approach based on economic benefits to the Central Asian states in exchange for geopolitical loyalty to Moscow. The Central Asian states are the last citadel of Russia's sphere of influence outside its own borders. There is an invitation to develop a plan for the possible consequences of anticipated or upcoming changes and implications of drawdown by NATO forces (ISAF) from Afghanistan and the post-2014 implications for security in Central Asia.

Integration of Russia with Central Asia is at a critical stage. Further development of the integration of Russia with the countries of Central Asia is fraught with partial loss of independence of the countries of the region. The greatest threat of the loss of economic and political sovereignty is looming over Kazakhstan. Due to the fact that the government of Kazakhstan is experiencing a lot of pressure on the part of Russia, integration within the Customs Union and the Eurasian Union will continue.

Kazakhstan, due to its geography and geopolitics needs more political support from the West 
than any other country of the region. The Silence of the West towards strengthening of Russia's interests in Central Asia is perceived by the national governments of Kazakhstan, Uzbekistan, Kyrgyzstan, Tajikistan and Turkmenistan, like the unwillingness of the West to intervene in the situation in Central Asia. After the war between Georgia and Russia in 2008, many believe that the West does not intend to take a full part in the development of strategic cooperation with the countries of Central Asia and the former Soviet republics as a whole.

\section{Recommendations}

The concept of regionalism is supported by western countries and European countries. The regional block is get support from Western states which reflects the interests of all countries of the region. USA and other groups also have their own interest in the region. National governments of Uzbekistan, Kyrgyzstan, Tajikistan Kazakhstan and Turkmenistan are concerned in regard to human rights violations and lack of political liberalization. The withdrawal of NATO forces is not a major issue of concern of national governments of Kazakhstan, Uzbekistan, Kyrgyzstan, Tajikistan and Turkmenistan.

Secondly, the accession of Ukraine's to the European Union and strong cooperation with Georgia. Ukraine's ability to reshape the relationship with the West and Belarus.

Thirdly, the dependence of the countries of Central Asia on Russia keeps in account by USA and European Union. There is a ground reality for dependence of Kazakhstan's on Russia. It is no need with the issues of bilateral cooperation to bind the questions of democratization of Kazakhstan or other Central Asian countries. The independence of the national governments of Kazakhstan, Uzbekistan, Kyrgyzstan, Tajikistan and Turkmenistanis important to preserve for in view of western diplomacy. The interests of the whole region lie in it as number one priority. The European Union and the West has to be a clear position toward Russian policy of integration in Central Asia. (Nikitin, 2008)

\section{Bibliography}

Halford J. Mackinder. (n.d.). "The Round World and the Winning of the Peace," Foreign.

CDDRL. (1993). CDDRL. Working Paper Domestic and International Influences on the Collapse of the Soviet Union (1991) and Russia's Initial Transition to Democracy (1993.). Working paper.

Gill, G. ( 1995, pp. 1140-1141, Winter). The Collapse of a Single-Party System: The Disintegration of the CPSU. Local Power and Post-Soviet Politics. by Theodore H. Friedgut; Jeffrey W. Hahn Review by: John Löwenhardt Slavic Review,. Retrieved from Vol. 54, No. 4.

Gleason, G. (1991-1992 pp141-163, Summer). The Federal Formula and the Collapse of the USSR . Retrieved March 17, 2014, from Publius, Vol. 22, No. 3, The State of American Federalism, 1991-1992 : Oxford University Press Stable URL: http://www.jstor.org/stablr/3330257

Hil, R. (2005, March-Appril 06). The Collapse of the Soviet Union History Ireland, Vol. 13, 


\section{Macrothink}

Journal of Public Administration and Governance

ISSN 2161-7104

2015, Vol. 5, No. 1

No. 2, pp. 37-42 Published by: Wordwell Ltd. Stable . Retrieved March Accessed: 06/03/2014 13:11, 2014, from History Ireland, Vol. 13, No. 2 (Mar. - Apr., 2005): URL: http://www.jstor.org/stable/27725240 . Accessed: 06/03/2014 13:11

Jayashekar. (1993, Sep 18). CIS: Economic Reintegration or Disintegration? Source: Economic and Political Weekly, Vol. 28, No. 38 )Published by: Economic and Political Weekly Stable URL: http://www.jstor.org/stable/4400169 . Access, pp. pp 1998-2003.

Khan, S. A. (n.d.). The fall of the Soviet Union: The fall of a state or the fall of an ideology. Retrieved from http://www.jstor.org/stable

Kratochwil, R. K. (1994, Spring). Understanding Change in International Politics: The Soviet Empire's Demise and the International System. Retrieved Janrary 09, 2012, from The MIT Press Stable (International Organization Vol.48,.No2: http:// www.jstore.org/stable/27006931

Libman, A. (2007 pp 401-430, May). Regionalization and Regionalism in the Post-Soviet Space: Current Status and Implications for Institutional Development. Retrieved from Europe Asia Studies Vil.59 No 3: http:// www.jstore.org/ stable/20451361

Mackinder, H. J. (1993). The Round World and the Winning of Peace,. Foriegn Affairs Vol 21, No 4, pp595-605.

Nikitin, A. (2008, Jun 2). Russian Foreign Policy in The Fragmented Post-Soviet Space. : International Journal on World Peace, Vol. 25 Published by: Professors World Peace Academy. Stable URL: http://www.jstor.org/stable/20752831 ., pp. pp 7-31.

Report. (September 2004). Transition in the CIS: Achievements and Challenges. Moscow: The Academy for National Economy .

Sdasyuk, G. V. (2000 pp42-52, July-August). Russia: Problems of Regional Integration in Transitional Economy . Retrieved from Social Scientist, Vol. 28, No. 7/8 : http://www.jstor.org/stable/3518234. Access

Wlodek, L. (2004 pp71-84). Identity Politics in Post-Soviet Reality Tajikistan's Case . Retrieved from Polish Sociological Review, No. 145 : (Polish Sociological Association) Stable URL: http://www.jstore.org.?stable/4127883 